\title{
PENGARUH KEPEMILIKAN ULTIMAT \\ TERHADAP KEINFORMATIFAN LABA PADA \\ PERUSAHAAN MANUFAKTUR YANG TERDAFTAR \\ DI BEI
}

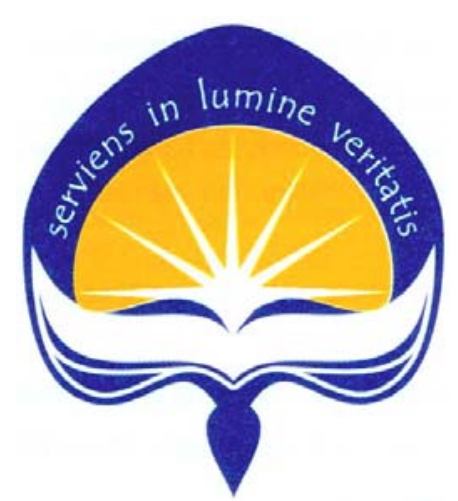

Disusun oleh :

Isabella Henny Susilowati

NPM : 090417561

\section{Pembimbing :}

I Putu Sugiartha Sanjaya

PROGRAM STUDI AKUNTANSI

FAKULTAS EKONOMI

UNIVERSITAS ATMA JAYA YOGYAKARTA

Jalan Babarsari 43-44, Yogyakarta 


\author{
PENGARUH KEPEMILIKAN ULTIMAT \\ TERHADAP KEINFORMATIFAN LABA PADA \\ PERUSAHAAN MANUFAKTUR YANG TERDAFTAR DI BEI \\ Isabella Henny Susilowati \\ Pembimbing : \\ I Putu Sugiartha Sanjaya \\ Program Studi Akuntansi, Fakultas Ekonomi \\ Universitas Atma Jaya Yogyakarta \\ Jalan Babarsari 43-44, Yogyakarta
}

\begin{abstract}
Kepemilikan ultimat adalah kepemilikan secara langsung dan tidak langsung pada perusahaan publik untuk mengidentifikasi pemilik ultimat peusahaan publik. Pemilik ultimat yang memiliki hak kontrol lebih besar dari hak aliran kasnya disebut pemegang saham pengendali. Hal ini menyebabkan masalah antara pemegang saham pengendali dan pemegang saham non pengendali, sehingga dapat mempengaruhi keinformatifan laba. Keinformatifan laba adalah informasi laba yang dapat mempengaruhi return saham.

Penelitian ini menggunakan 149 perusahaan manufaktur yang terdaftar di BEI tahun 2004-2009. Data yang digunakan pada penelitian ini adalah laba dan ekuitas pada laporan keuangan tahunan, serta kepemilikan perusahaan. Pengujian ini menggunakan metode analisis regresi moderasian dengan variabel moderasi Cash Flow Right Leverage (CFRL). CFRL adalah selisih hak kontrol dengan hak aliran kas.

Hasil penelitian ini menunjukkan bahwa perbedaan hak kontrol dengan hak aliran kas yang dimiliki pemegang saham pengendali membuat keinformatifan laba menjadi rendah karena pemegang saham dapat mempengaruhi kebijakan untuk membuat informasi akuntansi, sehingga membuat keinformatifan laba menjadi rendah.
\end{abstract}

Kata Kunci : kepemilikan ultimat, hak kontrol, hak aliran kas, keinformaifan laba. 


\section{Pendahuluan}

\subsection{Latar Belakang}

Perusahaan di Indonesiarata-rata memiliki masalah keagenan antara pemegang saham pengendali dan pemegang saham non pengendali. Hal ini didukung oleh penelitian Siregar (2006), Sanjaya (2010), Febrianto (2005) yang membuktikan bahwa terjadi masalah keagenan antara pemegang saham pengendali dan pemegang saham non pengendali di Indonesia. Masalah keagenan ini terjadi karena terdapat pemisahan hak kontrol dan hak aliran kas. Pemisahan hak kontrol dan hak aliran dapat diidentifikasikan dengan konsep kepemilikan ultimat.

Perbedaan hak kontrol dan hak aliran kas yang besar menyebabkan terjadinya ekspropriasi manfaat privat yang dilakukan oleh pemegang saham pengendali akan merugikan pemegang saham non pengendali. Hal ini dikarenakan jumlah hak kontrol yang lebih besar ini mengakibatkan pemegang saham pengendali termotivasi melakukan ekspropriasi manfaat privat. Apabila jumlah hak kontrol sama besar dengan jumlah hak aliran kasnya, pemegang saham pengendali tidak akan melakukan ekspropriasi manfaat privat. Hal ini dikarenakan jika pemegang saham pengendali melakukan ekspropriasi, yang akan menderita kerugian terbesar adalah pemegang saham pengendali itu sendiri.

Fenomena besarnya perbedaan hak kontrol dengan hak aliran kas yang terjadi di Indonesia ditunjukkan pada kasus PT. Bank Century Tbk. Robert Tantular sebagai pemegang saham ultimat PT. Bank Century memberikan kredit bank kepada PT. Wibowo Wadah Rejeki dan PT. Accent Investment Indonesia. Bank Century memberikan hutang kepada kedua perusahaan yang pemiliknya adalah Robert Tantular (Siringoringo, 2009 ; Sanjaya, 2010). Kasus ini menandakan bahwa Robert Tantular sebagai pemegang saham pengendali yang melakukan ekspropriasi. Robert Tantular ini mempunyai saham Bank Century atas namanya sendiri dan mempunyai saham Bank Century atas nama perusahaan lain yang dikendalikan oleh Robert Tantular. 
Kasus di atas menunjukkan bahwa Indonesia memiliki masalah keagenan antara pemegang saham pengendali dan non pengendali. Pemegang saham pengendali dalam kasus tersebut otomatis mempunyai hak kontrol yang lebih besar daripada hak aliran kasnya.Didukung oleh penelitian Claessens et al. (2000b) menyatakan bahwa dua pertiga perusahaan publik di Indonesia dikuasai oleh beberapa kelompok pemegang saham pengendali. Pemegang saham pengendali dalam sebuah perusahaan mempunyai pemegang saham pengendali satu atau sekelompok yang biasanya adalah keluarga, kemudian menjual sebagian kecil saham ke publik.

Umumnya, pemegang saham pengendali yang mempunyai hak kontrol lebih besar ikut terlibat dalam manajemen perusahaan atau bagian dari manajemen perusahaan. Oleh karena itu pemegang saham pengendali dapat mengendalikan perusahaannya sesuai dengan kepentingannya. Hal ini dapat menyebabkan informasi laba menjadi tidak informatif. Laba yang tidak informatif ini dapat menyesatkan pengguna laporan keuangan khususnya pengguna eksternal. Informasi laba seharusnya memberi gambaran kemampuan sebuah perusahaan dalam beroperasi.

Perusahaan yang go public dapat memperjualbelikan saham secara luas di pasar sekunder. Harga saham di pasar sekunder ditentukan oleh ask dan bid antara penjual dan pembeli. Biasanya ask dan bid dipengaruhi baik faktor internal maupun eksternal perusahaan. Faktor internal merupakan faktor yang berhubungan dengan tingkat kinerja perusahaan yang dapat dikendalikan oleh manajemen perusahaan, seperti kinerja manajemen perusahaan. Kedua, faktor eksternal, yaitu hal-hal di luar kemampuan manajemen perusahaan untuk mengendalikannya, seperti perubahan kurs. Investor menanamkan dananya pada sebuah perusahaan sangat berkepentingan terhadap laba saat ini dan laba yang diharapkan di masa yang akan datang. Hal ini menyebabkan harga saham yang terjadi mengandung informasi laba yang disebut keinformatifan laba. 
Penelitian Fan dan Wong (2000) dilakukan di Asia Timur menyatakan bahwa perbedaan hak kontrol dengan hak aliran kas dapat mempengaruhi keinformatifan laba dalam perusahaan. Perbedaan ini dapat menjadikan laba kurang informatif. Hal ini dikarenakan pengelolaan perusahaan yang tidak transparan. Indonesia memiliki kondisi sistem pengelolaan yang kurang transparan, sehingga pemonitoran akan lebih sulit untuk dilaksanakan jika kepemilikan seseorang meningkat dan ada konsentrasi kepemilikan pada satu orang atau kelompok. Oleh karena itu, diperlukan pembuktian bahwa fenomena kepemilikan ultimat di Indonesia akan mempengaruhi keinformatifan laba.

\subsection{Rumusan Masalah}

Perusahaan di Indonesia yang memiliki kepemilikan terkonsentrasi akan timbul masalah keagenan antara pemegang saham pengendali dan pemegang saham non pengendali. Hal ini disebabkan adanya pemisahan hak kontrol dengan hak aliran kas. Perbedaan hak kontrol yang besar akan mengakibatkan pemegang saham pengendali melakukan ekspropriasi manfaat privat yang merugikan pemegang saham non pengendali. Jika dihubungkan struktur kepemilikan ultimat dengan informasi laba akan timbul pertanyaan apakah perbedaan hak kontrol dangan hak aliran kas berpengaruh terhadap keinformatian laba?

\subsection{Tujuan Penelitian}

Dari rumusan masalah di atas penelitian ini bertujuan untuk membuktikan bahwa perbedaan hak kontrol dengan hak aliran kas dapat mempengaruhi keinformatifan laba. 


\section{Kajian Teori dan Pengembangan Hipotesis}

\subsection{Kajian Teori}

\subsubsection{Teori Keagenan}

Menurut Villalonga dan Amit (2006) konflik ini termasuk Agency Problem II. Dalam Agency Problem II mempunyai prinsipal adalah pemegang saham non pengendali dan agennya adalah pemegang saham pengendali.Pemegang saham pengendali sebagai agen karena pemegang saham pengendali dapat merupakan bagian dari manajer dan mengelola langsung perusahaan.Pemegang saham non pengendali sebagai prinsipal yang tidak dapat mengelola perusahaan karena kepemilikan sahamnya kurang dan hanya membeli saham perusahaan di bursa.Munculnya masalah agensi ini karena adanya insentif dan kemampuan pemegang saham pengendali untuk medapatkan manfaat privat.Manfaat privat inilah yang mendorong pemegang saham pengendali untuk mempertahankan kontrol perusahaan. Manfaat privat atas kontrol lebih besar apabila kepemilikannya terkonsentrasi. Menurut penelitian Sanjaya (2010) terdapat dua konsep pada masalah keagenan yaitu entrenchment effect dan alignment effect. Entrenchment effect adalah akibat dari tindakan yang dilakukan pemegang saham pengendali dilindungi oleh hak kontrol, sehingga terlibat dalam penyalahgunaan kekuasaan. Alignment effect adalah tindakan pemegang saham pengendali yang sinkron dengan kepentingan pemegang saham non pengendali.

\subsubsection{Hak Kontrol dan Hak Aliran Kas}

Penyebab masalah keagenan adalah adanya perbedaan hak kontrol dengan hak aliran kas. Hak kontrol adalah hak pemegang saham untuk menentukan kebijakan perusahaan (Sanjaya, 2012). Hak aliran kas adalah hak pemegang saham pengendali untuk mendapatkan bagian keuntungan dari perusahaan (Hartono, 2009). Perbedaan hak kontrol dan hak aliran kas dapat ditunjukkan dengan cash flow right leverage (CFRL). CFRL yang besar berarti pemegang saham memiliki hak control yang lebih besar dari hak aliran kasnya. 


\subsection{Pengembangan Hipotesis}

Pengaruh perbedaan hak aliran kas dan hak kontrol terhadap keinformatifan laba

Berdasarkan konsep entrenchment effect, perusahaan dengan kepemilikan ultimat memiliki cash flow right leverage yang besar berarti pemegang saham pengendali memiliki hak kontrol yang lebih besar daripada hak aliran kasnya. Semakin besar hak kontrol yang dimiliki, semakin besar insentif dan kemampuan pemegang saham pengendali dalam melakukan ekspropriasi. Oleh karena itu, masalah keagenan antar pemegang saham pengendali dan pemegang saham non pengendali akan semakin besar. Hak kontrol yang besar menandakan bahwa terdapat pengaruh pemegang saham pengendali dalam mengendalikan perusahaan. Pemegang saham pengendali akan mengendalikan perusahaan untuk mendapatkan kepentingannya yang biasanya disebut dengan manfaat privat dari kontrol. Manfaat privat dari kontrol ini akan merugikan bagi pemegang saham non pengendali karena mengorbankan kepentingan pemegang saham non pengendali.

Pemegang saham pengendali melakukan ekpropriasi ini dengan cara pemegang saham pengendali mengontrol manajer atau merupakan bagian dari manajemen perusahaan itu, sehingga dapat mengendalikan perusahaan untuk melakukan manfaat privat atas kontrol tersebut. Pada saat manfaat privat atas kontrol yang dimiliki besar, pemegang saham pengendali akan berusaha untuk mengalokasikan sumber daya perusahaan untuk memaksimumkan manfaat privat. Apabila pemegang saham pengendali mempengaruhi manajer perusahaan, informasi akuntansi yang dikeluarkan menjadi kurang tidak informatif dan akurat. Keinformatifan laba yang rendah dapat menggambarkan bahwa dalam perusahaan adanya kemungkinan ekspropriasi yang dilakukan oleh pemegang saham pengendali.

Ha. Perbedaan antara hak kontrol dan hak aliran kas berpengaruh negatif terhadap keinformatifan laba. 


\section{Metode Penelitian}

\subsection{Sampel dan Data}

Sampel penelitian ini adalah perusahaan manufaktur yang terdaftar di BEI pada periode tahun 2004 sampai dengan 2006. Perusahaan yang digunakan adalah perusahaan yang melaporkan keuangannya dari tahun 2004-2006. Data perusahaan diambil dari database Indonesia Stock Exchange (IDX) dan data kepemilikan bersumber dari penelitian Sanjaya (2010).

\subsection{Variabel}

Variabel penelitian ini meliputi variabeldependen,variabel independen,variabel moderasi dan variabel kontrol.

\subsubsection{Variabel Dependen}

Variabel dependen dalam penelitian ini adalah cumulative abnormal return (CAR). Abnormal return adalah selisih antara tingkat keuntungan yang sebenarnyadan tingkat keuntungan yang diharapkan. Cumulative Abnormal Return (CAR) adalah jumlah dari abnormal return.Apabila CAR tinggi, return yang didapatkan lebih besar dari return yang diharapkan. Hal tersebut menandakan bahwa laba menjadi informatif dan akurat, serta dalam harga saham mengandung informasi laba yang menunjukkan tidak adanya ekspropriasi terhadap pemegang saham non pengendali.

\subsubsection{Variabel Independen}

Variabel independen dalam penelitian ini adalah laba bersih perusahaan (NI) yang menggunakan proksi Return On Equity atau ROE. Pengukuran laba ini mengacu pada Boubaker (2011).

\subsubsection{Variabel Moderasi}

Variabel moderasi penelitian ini meliputi adanya pemegang saham pengendali yang mempunyai perbedaan hak kontrol dan hak aliran kas. Perbedaan ini diukur dengan kepemilikan piramida yang mengacu pada Sanjaya (2010) dan Boubaker (2011), variabel cash fllow right leverage (CFRL) ditentukan sebesar selisih antara hak kontrol den hak aliran kas. 


\subsubsection{Variabel Kontrol}

Variabel kontrol dalam penelitian ini adalah nilai perusahaan (Q) yang diukur dengan nilai pasar ekuitas (market value of equity/MVE) dibagi nilai buku total asset. Pengukuran nilai perusahaan mengacu pada penelitian Boubaker (2011).

\subsection{Model Empiris}

Sebelum pengujian hipotesis dalam penelitian ini dilakukan: (1) analisis statistik deskriptif yang meliputi rata-rata, maksimum dan minimum, (2) pengujian asumsi klasik yang meliputi uji normalitas, uji heterokedastisitas, uji autokorelasi, dan uji multikolinealitas, dan (3) pengujian hipotesis.

Pengujian hipotesis tentang pengaruh perbedaan hak kontrol dengan hak aliran kas terhadap keinformatifan laba digunakan rumus berikut:

$$
\mathrm{CAR}_{\mathrm{it}}=\alpha+\beta_{1} \mathrm{NI}_{\mathrm{it}}+\beta_{2} \mathrm{CFRL}_{\mathrm{it}}+\beta_{3}\left(\mathrm{NI}_{\mathrm{it}} \mathrm{x} \mathrm{CFRL}_{\mathrm{it}}\right)+\beta_{4} \mathrm{Q}_{\mathrm{it}}+\varepsilon_{\mathrm{it}}
$$

Dalam analisis berganda peneliti memprediksi hasil untuk hipotesis penelitian mempunyai koefisien $\beta_{3}$ negatif dan signifikan kurang dari alpha, serta mempunyai nilai $\mathrm{t}$ negatif. Jika hal yang diprediksikan terjadi, akan mendukung hipotesis dalam penelitian ini. Hipotesis penelitian ini menyatakan bahwa perbedaan antara hak kontrol dan hak aliran kas berpengaruh negatif terhadap keinformatifan laba.

\section{Analisis dan Pembahasan}

\subsection{Gambaran Umum Objek Penelitian}

Penelitian ini mempunyai sampel dari tahun 2004-2006 sebanyak 422 perusahaan. Dari jumlah tersebut, sebanyak 273 perusahaan dikeluarkan karena tidak mempunyai data yang lengkap, modal perusahaan yang negatif. Setelah beberapa perusahaan dikeluarkan, jumlah sampel yang akan diteliti sebanyak 149 perusahaan. Jumlah pengamatan dalam 
penelitian ini untuk tahun 2004 sebanyak 47 perusahaan, tahun 2005 sebanyak 51 perusahaan dan tahun 2006 sebanyak 51 perusahaan. Pemilihan sampel penelitian ini ditunjukkan tabel berikut ini:

Tabel 4.1

Pemilihan Sampel

\begin{tabular}{|l|r|r|r|}
\hline \multicolumn{1}{|c|}{ Keterangan } & 2004 & 2005 & 2006 \\
\hline Perusahaan manufaktur yang go public & 148 & 136 & 138 \\
\hline $\begin{array}{l}\text { Dikurangi : } \\
\text { harga saham tidak lengkap }\end{array}$ & 38 & 20 & 27 \\
\hline $\begin{array}{l}\text { data tanggal laporan keuangan tidak } \\
\text { lengkap }\end{array}$ & 34 & 34 & 34 \\
\hline laporan keuangan tidak lengkap & 22 & 23 & 20 \\
\hline ekuitas yang negatif & 6 & 7 & 5 \\
\hline data kepemilikan tidak lengkap & 1 & 1 & 1 \\
\hline Sampel yang diuji & $\mathbf{4 7}$ & $\mathbf{5 1}$ & $\mathbf{5 1}$ \\
\hline
\end{tabular}

\subsection{Analisis Deskriptif}

Penelitian ini memiliki variabel dependen (cumulative abnormal return/CAR), variabel independen (net income / NI), variabel moderasi (cash flow right leverage/CFRL), variabel kontrol (nilai perusahaan/Q). Setelah pemilihan sampel, kemudian dilakukan analisis deskriptif pada variabel yang akan diteliti. Tabel dibawah ini menyajikan deskripsi variabel peneltian :

Tabel 4.2

Hasil Deskriptif

\begin{tabular}{|l|r|r|r|r|r|}
\hline & \multicolumn{1}{|c|}{$\mathrm{N}$} & \multicolumn{1}{c|}{ Minimum } & \multicolumn{1}{c|}{ Maximum } & \multicolumn{1}{c|}{ Mean } & \multicolumn{1}{c|}{ Std. Deviation } \\
\hline $\mathrm{CAR}$ & 149 & -.436103 & 1.044707 & .05732070 & .216960970 \\
$\mathrm{NI}$ & 149 & -16.111705 & 3.715249 & -.12971169 & 1.688585259 \\
$\mathrm{CFRL}$ & 149 & .000000 & .285600 & .02296309 & .060527761 \\
$\mathrm{NI}$ CFRL & 149 & -.155669 & .041578 & -.00082185 & .015857886 \\
$\mathrm{Q}$ & 149 & .022385 & 3.358275 & .58678890 & .655425635 \\
\hline
\end{tabular}


Penelitian ini menggunakan $\alpha=5 \%(0,05)$, awal pengujian normalitas menghasilkan signifikan sebesar 0 , yang berarti tidak berdistribusi normal residual penelitian ini. Kemudian, dilakukan trimming untuk dapat menjadi normal. Setelah ditrimming sebanyak 21 data, signifikan yang dihasilkan adalah 0,055 . Hasil ini lebih besar dari $\alpha=5 \%(0,05)$

\subsection{Uji Hipotesis dan Pembahasan Hipotesis}

Hipotesis penelitian ini memprediksi bahwa perbedaan hak kontrol dengan hak aliran kas berpengaruh negatif terhadap keinformatifan laba. Pengujian hipotesis ini menggunakan analisis regresi moderasian. Hipotesis ini terdukung apabila koefisien beta variabel $\mathrm{NI}$ *CFRL hasil regresi berganda adalah negatif dan signifikan, serta menghasilkan nilai t negatif. Hasil pengujian hipotesis ditunjukkan pada tabel di bawah ini :

\section{Tabel 4.3}

\section{Hasil Hipotesis}

\begin{tabular}{|c|c|c|c|c|c|c|}
\hline \multirow{2}{*}{\multicolumn{2}{|c|}{ Model }} & \multicolumn{2}{|c|}{$\begin{array}{l}\text { Unstandardized } \\
\text { Coefficients }\end{array}$} & \multirow{2}{*}{$\begin{array}{c}\begin{array}{c}\text { Standardized } \\
\text { Coefficients }\end{array} \\
\text { Beta }\end{array}$} & \multirow[t]{2}{*}{$\mathrm{t}$} & \multirow[t]{2}{*}{ Sig. } \\
\hline & & $B$ & Std. Error & & & \\
\hline \multirow{5}{*}{1} & (Constant) & $-0,033$ & 0,011 & & $-2,877$ & 0,005 \\
\hline & $\mathrm{NI}$ & 0,117 & 0,020 & 1,817 & 5,917 & 0,000 \\
\hline & CFRL & $-0,388$ & 0,131 & $-0,215$ & $-2,956$ & 0,004 \\
\hline & $\mathrm{NI}{ }^{\star} \mathrm{CFRL}$ & $-0,472$ & 0,097 & $-1,490$ & $-4,861$ & 0,000 \\
\hline & $\mathrm{Q}$ & 0,053 & 0,013 & 0,284 & 4,227 & 0,000 \\
\hline
\end{tabular}

Pengujian hipotesis menggunakan $\alpha=5 \%$, dengan model regresi berganda. Tabel di atas menunjukkan bahwa signifikan variabel NI*CFRL adalah 0 kurang dari 5\% yang berarti secara signifikan berpengaruh. Variabel NI*CFRL mempunyai arah negatif yang ditunjukkan oleh nilai $\mathrm{t}$ 4,861. Hasil pengujian ini mendukung hipotesis yang menyatakan bahwa perbedaan hak kontrol dengan hak aliran kas berpengaruh positif terhadap keinformatifan laba. Hasil uji hipotesis ini sejalan dengan konsep entrenchment effect. 
Hasil dari penelitian ini sejalan dengan penelitian Boubaker dan Sami (2011) yang melakukan penelitian di Perancis membuktikan bahwa perbedaan hak kontrol dengan hak aliran kas yang dimiliki oleh pemegang saham pengendali berpengaruh negatif terhadap keinformatifan laba. Hal ini dapat berpengaruh tentang kepercayaan pemegang saham non pengendali yang akan menurun terhadap informasi dalam perusahaan tersebut. Selain itu, hasil ini sejalan dengan penelitian Fan dan Wong (2000) di Asia Timur yang membuktikan bahwa perbedaan hak kontrol dengan hak aliran kas berpengaruh negatif terhadap keinformatifan laba.

Hasil penelitian ini menunjukkan bahwa perusahaan go public di Indonesia mempunyai masalah keagenan antara pemegang saham pengendali dan pemegang saham non pengendali. Dalam masalah keagenan ini biasanya pemegang saham pengendali akan melakukan ekspropriasi. Pemegang saham pengendali termotivasi untuk melakukan ekspropriasi karena mamiliki perbedaan hak kontrol dengan hak aliran kas yang besar. Perbedaan ini akan membuat laba yang disajikan tidak informatif dan akurat, sehingga dapat membiaskan ekspektasi pemegang saham non pengendali. Hal ini akan menyebabkan kepercayaan pemegang saham non pengendali akan menurun terhadap pelaporan laba perusahaan karena laba yang dilaporkan memiliki keinformatifan laba yang rendah. 


\section{Penutup}

\subsection{Simpulan}

Penelitian ini telah membuktikan terdapat pengaruh negatif perbedaan hak kontrol dengan hak aliran kas. Penelitian yang telah dilakukan dapat disimpulkan bahwa beberapa perusahaan go public di Indonesia melakukan ekspropriasi untuk mendapatkan manfaat privat. Ekspropriasi ini disebabkan karena adanya perbedaan hak kontrol dengan hak aliran kas yang besar yang dapat ditelusuri menggunakan kepemilikan ultimat. Dengan konsep struktur kepemilikan ultimat ini akan teridentifikasi pemilik ultimat pada perusahaan publik. Pemilik ultimat dengan hak kontrol yang lebih besar dari hak aliran kasnya akan terlibat dalam manajemen perusahaan karena hak kontrol adalah hak pemegang saham untuk mengontrol perusahaan dengan mengeluarkan kebijakan. Maka dari itu, pemegang saham pengendali melakukan ekspropriasi, sehingga membuat keinformatifan laba menjadi menurun. Hal ini mengakibatkan laporan laba menjadi tidak akurat, informasi laba yang terkandung dalam harga saham akan menjadi bias atau tidak akurat.

\subsection{Keterbatasan}

Dalam penelitian pasti ada keterbatasan yang tidak dapat dihindarkan.Keterbatasan yang ditemukan oleh peneliti untuk penelitian ini adalah kurang tersedianya secara lengkap tanggal pelaporan keuangan.Banyak data harga saham yang hilang ketika tanggal pelaporan keuangan. Kurang terbukanya kepemilikan saham di perusahaan go public.

\subsection{Saran}

Peneliti selanjutnya akan lebih baik meneliti lebih lanjut pengaruh kepemilikan ultimat selain terhadap keinformatifan laba, manajemen laba dan dividen. Jika peneliti selanjutnya meneliti dengan variabel dependen selain keinformatifan laba, manajemen laba dan dividen akan lebih membuktikan bahwa terjadi konflik keagenan kedua di Indonesia. Konflik keagenan kedua adalah konflik antara pemegang saham pengendali dengan pemegang saham non pengendali. 